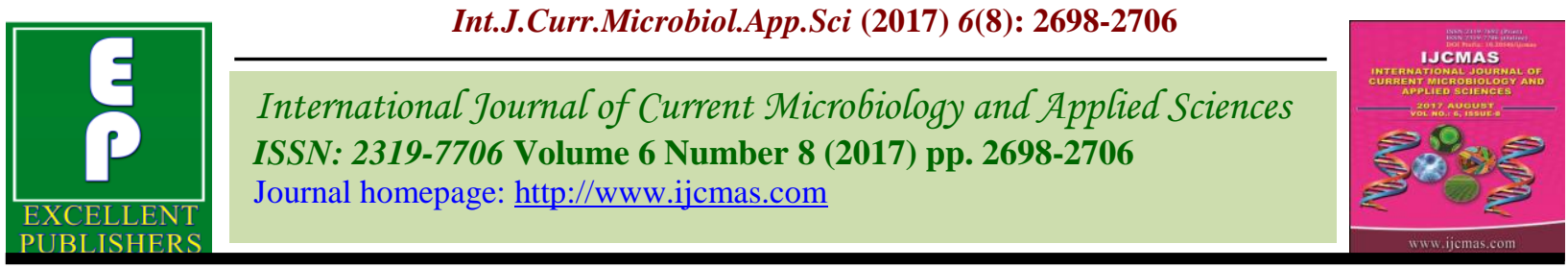

Original Research Article

https://doi.org/10.20546/ijcmas.2017.608.323

\title{
Performance of Elite Genotypes of Tomato (Solanum lycopersicum Mill) for Yield and Quality Traits under Hisar Condition, Haryana, India
}

\author{
Pradeep Kumar Jatav ${ }^{\text {* }}$, Sachin S. Chikkeri ${ }^{2}$, Nalla Manoj Kumar ${ }^{1}$, \\ M.V. Bharathkumar ${ }^{2}$, V.P.S. Panghal ${ }^{2}$ and Dharamveer Duhan ${ }^{2}$ \\ ${ }^{1}$ Department of Vegetable Science, IARI, New Delhi, India \\ ${ }^{2}$ Department of Vegetable Science, CCS HAU, Hisar, India \\ *Corresponding author
}

\begin{abstract}
A B S T R A C T
The experiment was carried out at research farm of the department of vegetable science, CCS Haryana Agricultural University, Hisar during spring summer

Keywords season of 2014-15 to study performance twenty-three tomato genotypes for yield and quality traits. Among all the genotypes, AVT-1-2 had highest plant height

Tomato, Elite genotypes,

Evaluation, Yield and

Article Info

Accepted:

23 June 2017

Available Online:

10 August 2017 $(140.33 \mathrm{~cm})$ and maximum number of branches per plant was observed in AVT-24 (7.60). The highest values for number of flowers per cluster were recorded in genotype AVT-2-2 (6.67). The genotype Hisar Arun had the highest number of fruits per plant (38.33) and AVT-2-7 had maximum number of fruits per truss (4.23). The maximum fruit yield per plant was recorded in genotype DVRT-3 $(1540.00 \mathrm{~g})$. The maximum polar and equatorial diameter of fruit was recorded in genotype AVT-2-6 $(5.10 \mathrm{~cm})$ and Punjab Kesari $(6.24 \mathrm{~cm})$, respectively. The maximum number of locules was registered with genotype DVRT-3 (6.20) and fruit weight with H-86 (64.03 g). The genotype PKM-1 had highest TSS $\left(8.43^{\circ}\right.$ Brix $)$ and highest acidity was recorded in H-86 (0.90). The minimum days was taken to ripening in genotypes Hisar Arun (79.00).
\end{abstract}

\section{Introduction}

Tomato (Lycopersicon esculentum Mill.), a member of Solanaceae family, is native of Andean region that includes parts of Colombia, Ecuador, Peru, Bolivia and Chile (Rick 1973, Taylor 1986).It is one of the most popular vegetable crops grown widely all over the world as it is a very versatile vegetable, ranking second in importance to potato in many countries. It is often referred to as a luxury crop because of its high consumption rate in developed and developing countries. In England, it is popularly known as Love Apple and is grown in home, market and truck gardens. Whatever has been the early history of its cultivation, the popularity of tomato has increased rapidly from the middle of nineteenth century to the present time. It is also a forcing crop being grown in greenhouse in off-season, thus, it has now become a good source of income to small and marginal farmers.

In India, it ranks second among vegetables in area and production and occupies an area of 0.88 million hectares with a production of 18.70 million tonnes and average yield of 
21.2 tonnes per hectare (anonymous, 2015). In Haryana, its area and production during 2012-2013 was 22606 ha and 38232 tonnes, respectively, representing eight major tomato growing districts of Karnal, Yamuna Nagar, Mewat, Kurukshetra, Gurgoan, Ambala, Sonipat and Faridabad in the state.

The ripe tomato fruits are consumed fresh as salad or after cooking. A large proportion of tomato is utilized in the preparation of various value added durable products such as puree, paste, powder, ketchup and sauce. The fully ripened whole fruits are canned, while the green unripe fruits are used for making pickles and chutney. In fact, tomato tops the list of processed vegetables and occupies a distinct place in the realm of vegetables because of its large-scale utilization and high nutritive value, as it supplies lycopene, ascorbic acid and $\beta$-carotene (potent antioxidants), and add colour and flavour, therefore, in many countries, it is considered as poor man's orange (Singh et al., 2004).

The production of tomato is highly influenced by environmental factors such as temperature, light, relative humidity and carbon dioxide level in the atmosphere. Being a warm season crop and reasonably resistant to heat and drought, it can be grown under a wide range of soil and temperature but the most optimum range of temperature for its record yield is 20 to $24^{\circ} \mathrm{C}$ but there should be 5 to $8^{\circ} \mathrm{C}$ difference between day and night temperature for getting higher yield from this crop. The mean temperature below $16^{\circ} \mathrm{C}$ and above $27^{\circ} \mathrm{C}$ is not desirable for its cultivation. Lycopene responsible for its red colour is synthesized highest at the temperature range of 21 to $24^{\circ} \mathrm{C}$.

\section{Materials and Methods}

An experiment was carried out at Research Farm and Laboratory of the Department of
Vegetable Science, CCS Haryana Agricultural University, Hisar which is located at latitude of $29^{\circ} 10^{\prime}$ North, longitude of $75^{\circ} 46^{\prime}$ East and at an altitude of 215.2 meters above mean sea level on south western border of the Rajasthan state and at a distance of about $175 \mathrm{~km}$ in west of the national capital city New Delhi having connectivity with National Highway Number 10, during spring-summer of the year 2014-15.

The climate of Hisar is semi-arid and subtropical with hot and dry winds during summer months. Warm humid in monsoon and cold dry weather in winter are the general features of this region. Both, winter and summer are usually harsh to bear upon. The mean minimum and maximum temperature exhibit wide range. A maximum temperature zooming 44 to $48^{\circ} \mathrm{C}$ during summer and temperature dipping as low as to freezing point accompanied with chill frost in winter is of common occurrence.

The seeds of twenty three germplasm lines including released varieties were procured from different sources (Table 1). The seedlings were raised in outdoor nursery beds in the field. The seeds of all twenty lines after treating with Captan @ $2 \mathrm{~g} / \mathrm{kg}$ were sown in rows $10 \mathrm{~cm}$ apart in last week of November 2014. The beds after sowing seeds were covered with fine compost, and water was sprinkled regularly with a fine rose-can.

The beds were kept moist until the seedlings emerged out in the beds. The nursery beds were covered with transparent polythene sheet to protect the seedlings from frost and cold waves. After germination, proper care was taken to ensure the proper growth of seedlings in the nursery. Seedlings became ready for transplanting in the last week of January 2015. The experimental design which was followed for analysis of data is randomized block design with the three replications. 
Five plants in each entry were selected randomly and tagged. These tagged plants were used for recording observations for plant height $(\mathrm{cm})$, number of branches per plant, days to $50 \%$ flowering, number of flowers per cluster, number of trusses per plant, number of fruits per truss, number of fruits per plant, total fruit yield per plant (g), average fruit weight $(\mathrm{g})$, polar diameter $(\mathrm{cm})$, equatorial diameter $(\mathrm{cm})$, number of locules per fruit, total soluble solids (\%), acidity (\%), ascorbic acid (mg/100 g) and days to ripening.

\section{Results and Discussion}

The analysis of variance indicated significantly higher amount of variability among the genotypes for all the characters studied viz., plant height, number of branches per plant, days to $50 \%$ flowering, number of flowers per cluster, number of trusses per plant, number of fruits per truss, number of fruits per plant, equatorial diameter of fruit, polar diameter of fruit, number of locules per fruit, total soluble solids, average fruit weight, total fruit yield per plant, ascorbic acid content, acidity and days to ripening (Table 2). The mean performance of different genotypes for different characters and grand mean for different characters are presented in table 3 .

\section{Plant height (cm)}

The range of plant height was from 59.73 to $140.33 \mathrm{~cm}$, with average plant height 90.14 $\mathrm{cm}$ (Table 3). The maximum plant height was recorded in genotype AVT-1-2 (140.33 cm) and the lowest plant height in Punjab Upma $(59.73 \mathrm{~cm})$.

Other varieties with plant height above one meter were AVT-2-1, AVT-2-6, Arka Abha, Arka Meghali, H-86 and Pusa Gaurav. Plant height of remaining genotypes was below one meter.

\section{Number of branches per plant}

The number of branches per plant ranged from 3.43 to 7.60 , with a mean value of 5.25 (Table 3). The maximum number of branches per plant was observed in AVT-2-4 (7.60) and minimum in PNR-7 (3.43). The other varieties with number of branches per plant above six were Arka Abha, Arka Sourabh, PKM-1 and Pusa Sadabahar, whereas, the remaining genotypes were having 3 to 6 branches per plant.

\section{Days to 50\% flowering}

Significant difference was recorded among the entries with respect to days to $50 \%$ flowering (Table 3). The average days taken to flowering in $50 \%$ plants was 49.33 days, with a range from 40.00 to 61.00 days. The minimum days was taken to flower in $50 \%$ plants by the genotype Arka Sourabh and AVT-2-7 (40.00), whereas, the maximum days was taken to flower in $50 \%$ plants by the genotype DVRT-2 (61.00).

\section{Number of flowers per cluster}

The average value for number of flowers per cluster ranged between 3.63 and 6.67 with a mean value of 5.33 (Table 3 ). The highest and lowest values for number of flowers per cluster were recorded in genotype AVT-2-2 (6.67) and H-86 (6.67), and Pusa Gaurav (3.63), respectively. The highest number of flowers per cluster was closely followed by AVT-2-3, AVT-2-6, Arka Abha, Arka Abha, Arka Meghali, PKM-1 and Pusa Sadabahar.

\section{Number of fruits per plant}

A wide variation was found among the genotypes for the number of fruits per plant, which significantly varied from 12.33 to 38.33 among the genotypes, with an overall mean of 21.78 (Table 3). The genotype Hisar 
Arun had the highest number of fruits per plant (38.33) and Arka Sourabh showed lowest number of fruits per plant (12.33). The other genotypes with more than 25 fruits per plant were AVT-2-4, AVT-2-7, Arka Vikas and Punjab Kesari. Twelve genotypes were recorded with fruits per plant lower than general mean and the remaining 11 genotypes had the number of fruits per plant above the general mean.

\section{Number of fruits per truss}

The number of fruits per truss varied significantly among the genotypes investigated (Table 3 ). The number of fruits per truss ranged from 1.33 to 4.23 , with a mean value of 2.62 . The maximum number of fruits per truss was recorded in genotype AVT-2-7 (4.23) and minimum in genotype Punjab Upma (1.33). The other genotypes, i.e., Hisar Arun, Punjab Ratta and DVRT-3, showed good number of fruits per truss. The results were in accordance to (Ahirwar and Prashad, 2013).

\section{Number of trusses per plant}

The tomato genotypes studied in the present investigation showed a wide range of variation, i.e., from 5.90 to 15.50 trusses per plant, with a mean value of 9.84 trusses (Table 3). The genotype AVT-2-4 (15.50) recorded with highest number of trusses per plant, whereas, the genotype AVT-2-1 (5.90) showed the minimum number of trusses per plant. Among all the genotypes studied, ten genotypes were having number of trusses per plant above mean value and remaining thirteen genotypes were lower than the mean value.

\section{Polar diameter of fruit (cm)}

There were significant differences among genotypes for polar diameter of fruit, which ranged from 2.33 to $5.10 \mathrm{~cm}$, with a mean value of $3.86 \mathrm{~cm}$ (Table 3 ). The maximum polar diameter of fruit was recorded in genotype AVT-2-6 $(5.10 \mathrm{~cm})$ and minimum in AVT-2-1 (2.33).

The other genotypes showed polar diameter above the mean value were AVT-2-2, AVT-27, AVT-1-2 Arka Abha, Arka Vikas, Arka Alok, Arka Meghali, PKM-1, Pusa Sadabahar, Punjab Upma, Punjab Kesari, Pusa Gaurav and DVRT-2, whereas, the remaining genotypes had the polar diameter of fruit below mean value.

Table.1 List of germplasm lines and standard released varieties included in the study

\begin{tabular}{|c|l|c|l|}
\hline Sr. No. & Genotype & Sr. No. & Genotype \\
\hline 1. & AVT-2-1 & 13. & PKM-1 \\
\hline 2. & AVT-2-2 & 14. & Pusa Sadabahar \\
\hline 3. & AVT-2-3 & 15. & PNR-7 \\
\hline 4. & AVT-2-4 & 16. & H-86 \\
\hline 5. & AVT-2-6 & 17. & Punjab Upma \\
\hline 6. & AVT-2-7 & 18. & Punjab Ratta \\
\hline 7. & AVT-1-2 & 19. & Sel-7 \\
\hline 8. & Arkaabha & 20. & Punjab Kesari \\
\hline 9. & ArkaVikash & 21. & DVRT-2 \\
\hline 10. & Arka Alok & 22. & Pusa Gaurav \\
\hline 11. & Arka Sourav & 23. & DVRT-3 \\
\hline 12. & Arka Meghali & & \\
\hline
\end{tabular}


Table.2 Analysis of variance for various characters in tomato

\begin{tabular}{|c|c|c|c|c|}
\hline \multirow{3}{*}{$\begin{array}{l}\text { Sr. } \\
\text { No. }\end{array}$} & \multirow{3}{*}{ Characters (df) } & \multicolumn{3}{|c|}{ Mean sum of squares } \\
\hline & & Replications & Genotypes & Error \\
\hline & & (2) & (22) & (44) \\
\hline 1. & Plant height $(\mathrm{cm})$ & 0.176 & $1,266.93 * *$ & 9.345 \\
\hline 2. & Number of branches per plant & 0.124 & $4.01 * *$ & 0.173 \\
\hline 3. & Days to $50 \%$ flowering & 5.52 & $111.14 * *$ & 2.68 \\
\hline 4. & Number of flowers per cluster & 0.04 & $1.79 * *$ & 0.11 \\
\hline 5. & Number of trusses per plant & 0.16 & $19.76^{* *}$ & 0.79 \\
\hline 6. & Number of fruits per truss & 0.40 & $1.78^{* *}$ & 0.08 \\
\hline 7. & Number of fruits per plant & 1.77 & $117.64 * *$ & 2.67 \\
\hline 8. & Total fruit yield per plant $(\mathrm{kg})$ & 0.0035 & $0.31 * *$ & 0.001 \\
\hline 9. & Average fruit weight $(\mathrm{g})$ & 7.63 & $344.53 * *$ & 4.03 \\
\hline 10. & Equatorial diameter of Fruit $(\mathrm{cm})$ & 0.20 & $1.88 * *$ & 0.20 \\
\hline 11. & Polar diameter of fruit $(\mathrm{cm})$ & 0.27 & $1.73 * *$ & 0.18 \\
\hline 12. & Number of locules per fruit & 0.27 & $1.33^{* *}$ & 0.08 \\
\hline 13. & Total soluble solids $(\%)$ & 0.08 & $5.03 * *$ & 0.05 \\
\hline 14. & Acidity (\%) & 0.0005 & $0.02 * *$ & 0.001 \\
\hline 15. & Ascorbic acid (mg/100g) & 1.33 & $27.78^{* *}$ & 3.91 \\
\hline 16. & Days to ripening & 0.45 & $542.31 * *$ & 6.58 \\
\hline
\end{tabular}


Table.3 Mean performance of tomato genotypes for yield and quality traits

\begin{tabular}{|c|c|c|c|c|c|c|c|c|c|c|c|c|c|c|c|c|}
\hline Genotypes & PLHT & NBR & DFF & $\begin{array}{c}\text { NFL } \\
\text { C }\end{array}$ & NFPT & NFPL & NTPL & PDF & $\begin{array}{c}\text { NLF } \\
\mathbf{R}\end{array}$ & $\begin{array}{c}\text { AFW } \\
\text { T }\end{array}$ & EDF & TSS & $\begin{array}{c}\mathbf{A C D} \\
\mathbf{Y}\end{array}$ & $\begin{array}{c}\text { ASA } \\
\text { D }\end{array}$ & DTR & FYPL \\
\hline AVT-2-1 & 125.00 & 4.97 & 48.67 & 4.40 & 2.23 & 12.43 & 5.90 & 2.33 & 3.80 & 46.00 & 3.35 & 5.00 & 0.71 & 20.00 & 89.00 & 0.60 \\
\hline AVT-2-2 & 77.67 & 5.23 & 46.33 & 3.63 & 2.87 & 17.83 & 8.27 & 3.99 & 3.53 & 40.03 & 4.12 & 6.10 & 0.63 & 19.67 & 82.33 & 0.72 \\
\hline AVT-2-3 & 75.10 & 5.20 & 50.33 & 5.77 & 3.43 & 21.27 & 7.33 & 3.17 & 4.33 & 52.63 & 3.72 & 6.20 & 0.72 & 24.00 & 92.67 & 1.09 \\
\hline AVT-2-4 & 90.23 & 7.60 & 46.67 & 4.83 & 2.93 & 31.83 & 15.50 & 3.53 & 4.20 & 38.00 & 4.08 & 6.00 & 0.71 & 21.33 & 88.67 & 1.16 \\
\hline AVT-2-6 & 107.00 & 6.57 & 45.33 & 6.37 & 2.20 & 21.50 & 12.20 & 5.10 & 4.00 & 40.93 & 5.06 & 4.50 & 0.66 & 27.00 & 88.33 & 0.93 \\
\hline AVT-2-7 & 62.40 & 5.03 & 40.00 & 5.40 & 4.23 & 30.17 & 7.93 & 4.66 & 3.23 & 36.00 & 4.77 & 4.00 & 0.62 & 25.00 & 81.93 & 0.96 \\
\hline AVT-1-2 & 140.33 & 6.00 & 49.00 & 5.27 & 2.23 & 19.60 & 9.73 & 4.32 & 4.13 & 25.27 & 4.15 & 4.40 & 0.68 & 20.00 & 80.33 & 0.52 \\
\hline Arka Abha & 101.77 & 6.08 & 51.33 & 5.70 & 1.40 & 16.17 & 9.47 & 4.00 & 3.93 & 40.67 & 4.57 & 5.23 & 0.65 & 25.67 & 84.67 & 0.63 \\
\hline Arka Vikash & 72.47 & 5.33 & 47.00 & 5.80 & 3.27 & 26.00 & 11.13 & 4.06 & 5.20 & 55.50 & 4.53 & 5.80 & 0.88 & 23.33 & 96.00 & 1.37 \\
\hline Arka Alok & 91.39 & 6.00 & 47.67 & 4.63 & 2.47 & 20.27 & 9.43 & 4.71 & 3.80 & 58.23 & 5.87 & 4.17 & 0.59 & 20.00 & 91.33 & 1.15 \\
\hline Arka Sourabh & 89.50 & 6.80 & 40.00 & 5.00 & 1.37 & 12.33 & 10.47 & 3.33 & 4.43 & 51.10 & 4.49 & 4.77 & 0.60 & 28.67 & $\begin{array}{c}103.6 \\
7\end{array}$ & 0.71 \\
\hline Arka Meghali & 108.60 & 4.93 & 52.00 & 5.80 & 2.17 & 18.40 & 8.93 & 4.47 & 4.00 & 40.33 & 5.47 & 6.23 & 0.77 & 26.00 & $\begin{array}{c}100.6 \\
7\end{array}$ & 0.73 \\
\hline PKM-1 & 83.07 & 6.07 & 51.00 & 6.03 & 2.77 & 23.67 & 11.23 & 4.48 & 3.60 & 39.67 & 4.99 & 8.43 & 0.63 & 23.00 & 92.33 & 0.92 \\
\hline Pusa Sadabahar & 87.30 & 7.23 & 43.33 & 5.93 & 2.40 & 18.33 & 8.53 & 4.17 & 3.93 & 41.00 & 4.58 & 5.40 & 0.70 & 27.33 & $\begin{array}{c}101.6 \\
7\end{array}$ & 0.75 \\
\hline
\end{tabular}




\begin{tabular}{|c|c|c|c|c|c|c|c|c|c|c|c|c|c|c|c|c|}
\hline PNR-7 & 83.67 & 3.43 & 51.00 & 5.00 & 2.50 & 23.33 & 10.23 & 3.30 & 4.17 & 34.37 & 4.44 & 4.17 & 0.72 & 21.00 & 94.00 & 0.78 \\
\hline H-86 & 101.57 & 4.77 & 42.67 & 6.67 & 2.70 & 21.83 & 12.00 & 3.32 & 4.73 & 64.03 & 4.74 & 4.10 & 0.90 & 24.33 & $\begin{array}{c}109.3 \\
3\end{array}$ & 1.32 \\
\hline Punjab Upma & 59.73 & 4.20 & 52.67 & 5.13 & 1.33 & 17.33 & 13.60 & 3.98 & 4.00 & 52.57 & 5.11 & 3.53 & 0.58 & 26.33 & $\begin{array}{c}108.6 \\
7\end{array}$ & 0.91 \\
\hline Punjab Ratta & 90.27 & 3.80 & 51.67 & 4.80 & 3.40 & 22.00 & 7.60 & 2.88 & 3.60 & 61.77 & 3.54 & 5.50 & 0.75 & 21.33 & $\begin{array}{c}116.0 \\
0\end{array}$ & 1.35 \\
\hline Hisar Arun & 67.23 & 3.60 & 40.33 & 5.17 & 3.90 & 38.33 & 14.00 & 2.67 & 5.03 & 40.27 & 3.17 & 5.87 & 0.66 & 22.43 & 79.00 & 1.49 \\
\hline Punjab Kesari & 76.27 & 5.40 & 57.00 & 5.13 & 2.27 & 28.33 & 6.60 & 4.48 & 5.00 & 46.20 & 6.24 & 5.40 & 0.76 & 27.67 & 104.6 & 1.28 \\
\hline DVRT-2 & 84.40 & 3.90 & 61.00 & 4.00 & 2.00 & 13.67 & 7.63 & 4.84 & 3.60 & 29.67 & 4.23 & 6.83 & 0.66 & 20.33 & 80.00 & 0.46 \\
\hline Pusa Gaurav & 124.27 & 4.20 & 58.33 & 6.67 & 2.53 & 21.33 & 12.07 & 4.21 & 4.50 & 60.07 & 5.77 & 7.67 & 0.56 & 19.33 & $\begin{array}{c}125.3 \\
3\end{array}$ & 1.26 \\
\hline DVRT-3 & 74.00 & 4.40 & 60.67 & 5.50 & 3.60 & 25.00 & 6.53 & 2.86 & 6.20 & 59.67 & 4.00 & 7.80 & 0.73 & 27.33 & $\begin{array}{c}122.0 \\
0\end{array}$ & 1.54 \\
\hline General Mean & 90.14 & 5.25 & 49.30 & 5.33 & 2.62 & 21.78 & 9.84 & 3.86 & 4.22 & 45.82 & 4.56 & 5.53 & 0.69 & 23.53 & 96.20 & 0.98 \\
\hline C.D. & 5.05 & 0.69 & 2.71 & 0.55 & 0.47 & 2.70 & 1.47 & 0.71 & 0.47 & 3.32 & 0.76 & 0.39 & 0.04 & 3.27 & 4.24 & 0.05 \\
\hline C.V. & 3.39 & 7.93 & $\mathbf{3 . 3 3}$ & 6.28 & 10.97 & 7.51 & 9.07 & 11.12 & 6.78 & 4.38 & 10.02 & 4.23 & 3.80 & 8.41 & 2.67 & 3.06 \\
\hline
\end{tabular}

NTPL: Number of trusses per plant; TSS: Total solunle solids; ASAD: Ascorbic acid; DFF: Days to $50 \%$ flowering FYPL: fruit yield per plant; NBR: Number of branches per plant; EDF: Equatorial diameter of fruit; PDF: Polar diameter of fruit NFLC: Number of flowers per cluster; NLFR: Number of locules per fruit; ACDY: Acidity; DTR: Days to ripening; NFPT: Number of fruit per truss; AFWT: Average of fruit weight (g); PLHT: plant height (cm); NFPL: Number of fruit per plant 


\section{Equatorial diameter of fruit (cm)}

Significant differences were observed among the genotypes for equatorial diameter of the fruit. It was ranged from 3.17 to $6.24 \mathrm{~cm}$, with a mean value of $4.56 \mathrm{~cm}$ (Table 3). The maximum equatorial diameter of fruit was recorded in genotype Punjab Kesari $(6.24 \mathrm{~cm})$ and minimum in genotype HisarArun $(3.17 \mathrm{~cm})$. The other genotypes having wide equatorial diameter above the mean were AVRT-2-6, AVRT-2-7, Arka Vikas, Arka Alok, Arka Abha, PKM-1, Pusa Sadabahar, H-86, Punjab Upma and Pusa Gaurav.

\section{Number of locules per fruit}

The number of locules per fruit ranged from 3.23 to 6.20 , with mean value of 4.22 (Table 3 ). The maximum number of locules was registered with genotype DVRT-3 (6.20), while minimum with the genotype AVT-2-7 (3.23). The other genotypes having number of locules per fruit above mean value were AVRT-2-3, Arka Vikas, Arka Sourabh, H-86, Hisar Arun, Punjab Kesari and Pusa Gaurav.

\section{Average fruit weight (g)}

The average fruit weight of tomato varied significantly among the genotypes. It ranged from 25.27 to $64.03 \mathrm{~g}$, with a mean value of $45.82 \mathrm{~g}$ (Table 3 ). The maximum fruit weight was recorded by the genotype H-86 (64.03 g) and minimum by AVT-1-2 (25.27 g). The other genotypes ranging above the mean were AVT2-1, AVT-2-3, Arka Vikas, Arka Alok, Arka Sourabh, Punjab Upma, Panjab Ratta, Punjab Kesari, Pusa Gaurav and DVRT-3. The remaining 12 genotypes were having the average fruit weight lower than the mean.

\section{Total soluble solid content of fruit (TSS ${ }^{\circ}$ Brix)}

Significant difference was noticed among genotypes for total soluble solids content of fruit at marketable stage. TSS of fruit ranged from 3.53 to $8.43^{\circ}$ Brix, with a mean value of $5.53^{\circ}$ Brix (Table 3). The highest TSS content of fruit was recorded with the genotype PKM-1 $\left(8.43^{\circ}\right.$ Brix), while the genotype Punjab Upma $\left(3.53^{\circ}\right.$ Brix) showed the lowest TSS content. The genotypes showed TSS greater than mean value were AVT-2-2, AVT-2-3, AVT-2-4, Arka Vikas, Arka Meghali, Hisar Arun, DVRT-2, DVRT-3 and Pusa Gaurav, whereas, the remaining thirteen genotypes had total soluble solids content of fruit less than general mean. Similar results were also obtained by Dar et al., (2012).

\section{Acidity (\%)}

The general mean of population in relation to acidity content of the fruit at marketable stage was 0.69. Acidity of the fruits at marketable stage ranged from 0.56 to 0.90 . The highest acidity was recorded in fruits of genotype H-86 (0.90), while lowest in fruits of Pusa Gaurav (0.56). Among the genotypes studied, AVT-2-1, AVT-2-3, AVT-2-4, Arka Vikas, Arka Meghali, Pusa Sadabahar, PNR-7, Punjab Ratta, Punjab Kesari and DVRT-3 had the acidity content of fruit more than general mean and the remaining twelve genotypes, i.e., AVT-2-2, AVT-2-6, AVT-2-7, AVT-1-2, Arka Abha, Arka Alok, Arka Sourabh, PKM-1, Punjab Upma, Hisar Arun and DVRT-2 had the acidity content of fruit less than general mean. Ramzan et al., (2014) had also found the similar kind of results.

\section{Ascorbic acid (mg/100g)}

Significant difference was observed among the genotypes for ascorbic acid content of fruit at marketable stage. The ascorbic acid content of fruit at marketable stage ranged from 19.33 to 28.67.

The general mean of population in relation to ascorbic acid content of fruit was 23.53 (Table 3 ). Among the genotypes studied, eleven genotypes had the ascorbic acid of fruit more than general mean, and the remaining twelve genotypes had the ascorbic acid of fruit less than general mean. 


\section{Days to ripening}

Significant differences were recorded among the entries with respect to days to ripening. The average days taken to ripen were 96.20, value ranging from 79.00 to 125.33 days. The minimum days was taken to ripening in genotypes Hisar Arun (79.00) and maximum in genotype Pusa Gaurav (125.33).

\section{Total fruit yield per plant (g)}

The fruit yield per plant of tomato evaluated varied significantly among 23 genotypes, ranging from 460.00 to $1540.00 \mathrm{~g}$. The general mean of genotypes was $980.00 \mathrm{~g}$. The maximum fruit yield per plant was recorded in genotype DVRT-3 $(1540.00 \mathrm{~g})$, while minimum in genotype DVRT-2 (460.00 g).

The most promising genotypes having fruit yield greater than general mean were AVT-2-3, AVT-24, Arka Vikas, Arka Alok, H-86, Punjab Ratta, Punjab Kesari, Hisar Arun and Pusa Gaurav, whereas, the remaining genotypes were found to have yield lower than general mean. These results were in supported by the findings Sharma and Thakur (2008), Prajapati et al., (2015). From the obtained results, it can be concluded that the genotypes studied in the present investigation exhibited a wide range of variation for various yield and yield contributing characters observed.

The most promising genotypes based on higher fruit yield and quality of fruits were DVRT-3, AVT-2-3, AVT-2-4, Arka Vikas, Arka Alok, H86, Punjab Ratta, Punjab Kesari, Hisar Arun and Pusa Gaurav which can be further subjected to selection for desired traits or can be utilized in different breeding programmes to exploit the heterosis.

\section{References}

Ahirwar, S. C. and Prashad, V. M. 2013. Variability patern in agro-morphological characters in tomato genotypes (Lycopersiconesculentum Mill.). Trends in Biosciences, 6(6): 758-761.

Anonymous, 2015. Final area and production estimates for horticulture crops for 20132014. National Horticulture Board, Gurgaon, Haryana,India.

Dar, R. A., Sharma, J. P., Nabi, A. and Chopra, S. 2012. Germplasm evaluation for yield and fruit quality traits in tomato (Solanumlycopersicon L.). African Journal of Agricultural Research, 7(46): 6143-6149.

Prajapati, S., Tiwari, A., Kadwey, S. and Jamkar, T. 2015. Genetic variability, heritability and genetic advance in tomato (Solanumlycopersicum Mill.). International Journal of Agriculture, Environment and Biotechnology, 8(2): 245-251.

Ramzan, T. N., Nawab, N. N., Hina, A., Noor, T. and Jillani, G. 2014. Estimation of Genetic components in $\mathrm{F}_{1}$ hybrids and their parents in determinate tomato. Journal of Agriculture Research, 52(1): 66-75.

Rick, C. M. 1973. Potential genetic resources in tomato species: clues from observations in native habitats. In: Genes, enzymes and populations (AM Srbed), Plenum Press, New York, pp 255-269.

Sharma, D. and Thakur, M. C. 2008. Evaluation of diallel progenies for yield and its contributing traits in tomato under mid-hill conditions. Indian Journal of Horticulture, 65(3): 297301.

Singh, J. K., Singh, J. P., Jain, S. K. and Joshi, A. 2004. Correlation and path coefficient analysis in tomato. Progressive Horticulture, 36(1): 82-86.

Taylor, I. B. 198). Biosystematics of the tomato. In: Tomato crop: a scientific basis for improvement (J Atherton and J Rudicheds). The Chapman and Hall, London, pp 1-34.

\section{How to cite this article:}

Pradeep Kumar Jatav, Sachin S. Chikkeri, Nalla Manoj Kumar, M.V. Bharathkumar, V.P.S. Panghal and Dharamveer Duhan. 2017. Performance of Elite Genotypes of Tomato (Solanum lycopersicum Mill) for Yield and Quality Traits under Hisar Condition, Haryana. Int.J.Curr.Microbiol.App.Sci. 6(8): 2698-2706. doi: https://doi.org/10.20546/ijcmas.2017.608.323 